\title{
Aansprakelijkheid van curator en bewindvoerder in insolventiezaken
}

\author{
$M r . E . A . L$. van Emden*
}

\section{Inleiding}

Het scenario dat een faillissementscurator of een in surseance of schuldsaneringsregeling aangestelde bewindvoerder (ook) persoonlijk wordt aangesproken voor handelen dat hij in functie heeft verricht, is bepaald niet denkbeeldig. $\mathrm{Al}$ in 1933 wees de Hoge Raad hierover een arrest ${ }^{1}$ en sindsdien zijn vele uitspraken gevolgd. In dit artikel geef ik aan de hand van gepubliceerde en niet-gepubliceerde jurisprudentie een overzicht van de verschillende scenario's die aanleiding kunnen geven tot een claim tegen de curator of bewindvoerder en de daarbij geldende stelregels. Omdat ik als advocaat betrokken was bij verschillende van de besproken uitspraken, wordt een overzicht gegeven zonder dat de uitspraken zelf becommentarieerd worden. Daaraan voorafgaand wordt het juridisch kader weergegeven.

\section{Juridisch kader}

\subsection{Het aangesproken vermogen en de toepasselijke norm $^{2}$}

Als het gaat om een schadevergoedingsvordering tegen een curator of bewindvoerder, zal eerst geduid moeten worden in welke hoedanigheid hij wordt aangesproken. Handelen en nalaten dat de curator of bewindvoerder in de uitoefening van zijn taak verricht, wordt in beginsel toegerekend aan de boedel, gelijk het in hoedanigheid verrichte handelen en nalaten van een bestuurder aan de door hem bestuurde vennootschap wordt toegerekend. Voor een door de curator of bewindvoerder in hoedanigheid gepleegde onrechtmatige daad, of begane toerekenbare tekortkoming, is de boedel dus het primair aan

Mr. E.A.L. van Emden is advocaat bij NN Advocaten (NationaleNederlanden) te Den Haag en buitenpromovendus aan de Radboud Universiteit Nijmegen.

1. HR 26 mei 1933, NJ 1933/870 m.nt. E.M. Meijers (Bink/Wiggermans). Zie eerder al Rb. Rotterdam 5 februari 1917, NJ 1917, p. 757.

2. Zie over het toetsingskader ook J.J. van Hees, Aansprakelijkheid van curatoren en bewindvoerders; aan de slag met Maclou, in: C.J.M. Klaassen e.a. (red.), Aansprakelijkheid in beroep, bedrijf of ambt, Deventer: Kluwer 2003, p. 239 e.v.; F.M.J. Verstijlen, De faillissementscurator, Deventer: W.E.J. Tjeenk Willink 1998; M.J. Borgers, Nieuwe (?) normen voor de faillissementscurator, AA 1996, afl. 9, p. 543-549; S.O.H. Bakkerus, De aansprakelijkheid voor onrechtmatige gedragingen van de curator, in: S.C.J.J. Kortmann e.a. (red.), De curator, een octopus, Deventer: W.E.J. Tjeenk Willink 1996, p. 173 e.v. Zie voorts in dit tijdschrift: E.M. van Orsouw, De persoonlijke aansprakelijkheid van de faillissementscurator: is er eindelijk (volledige) duidelijkheid?, MvV 2012, afl. 3, p. 65-73. te spreken vermogen. ${ }^{3}$ Dit wordt aangeduid als aansprakelijkheid in hoedanigheid/aansprakelijkheid q.q. Voor de vraag of de boedel - dus de curator of bewindvoerder q.q. aansprakelijk is, gelden de 'reguliere' regels voor aansprakelijkheid uit onrechtmatige daad. ${ }^{4}$ Uiteraard zal bij het invullen van deze norm wel betekenis toekomen aan de bijzondere taak en positie van de curator respectievelijk bewindvoerder.' Aansprakelijkheid q.q. leidt tot het ontstaan van een boedelschuld, die in beginsel de status van concurrente boedelschuld heeft. ${ }^{6}$ Vooral in het geval van een negatieve boedel, waarbij niet alle concurrente boedelschulden (geheel) betaald kunnen worden, wordt relevant of de curator of bewindvoerder ook persoonlijk aan te spreken valt. Dit wordt aangeduid als aansprakelijkheid pro se. Privéaansprakelijkheid kan voor een schuldeiser aantrekkelijk zijn omdat de curator of bewindvoerder voor zijn 'pro se'-aansprakelijkheid doorgaans dekking onder een beroepsaansprakelijkheidsverzekering heeft, zodat verhaal (tot op zekere hoogte) verzekerd is. ${ }^{7}$ Het enkele feit dat de boedel niet voldoende verhaal biedt, makkt de curator of bewindvoerder vanzelfsprekend nog niet persoonlijk aansprakelijk.

Juist omdat het bij 'pro se'-aansprakelijkheid gaat om persoonlijke aansprakelijkheid voor handelen dat in beginsel aan de boedel wordt toegerekend, geldt bij dit type aansprakelijkheid een drempel voor aansprakelijkheid. Uit het Maclou-arrest uit 1996 volgt dat voor persoonlijke aansprakelijkheid bepalend is of de curator heeft gehandeld zoals in redelijkheid wordt verwacht van een over voldoende inzicht en ervaring beschikken-

3. HR 10 januari 2003, ECLI:NL:HR:2003:AF0692, NJ 2003/196 m.nt P. van Schilfgaarde (Van Bentum Recycling/Mrs. Bos c.s. advocaten).

4. HR 24 februari 1995, ECLI:NL:HR:1995:ZC1643, NJ 1996/472 m.nt. W.M. Kleijn (Sigmacon II); HR 19 december 2003, ECLI:NL:HR: 2003:AN7817, NJ 2004/293 m.nt. P. van Schilfgaarde (Curatoren Mobell/Interplan).

5. HR 30 januari 2015, ECLI:NL:HR:2015:166, JOR 2015/243 (Verwiel/4PET).

6. Vgl. G.A.J. Boekraad, Afwikkeling van de faillissementsboedel, Deventer: W.E.J. Tjeenk Willink 1997, p. 229.

7. Curatoren en bewindvoerders in surseance zijn meestal advocaten, die op grond van art. 6.25 sub c Voda verplicht verzekeringsdekking moeten hebben voor hun handelen als curator. Daarnaast schrijft art. 7 van de Recofa-richtlijnen voor faillissementen en surseances een beroepsaansprakelijkheidsverzekering voor. Als bewindvoerder in de schuldsaneringsregeling worden regelmatig niet-advocaten aangesteld; ook zij plachten zich te verzekeren voor beroepsaansprakelijkheid. Art. 6 van de Recofa-richtlijnen voor schuldsaneringen vereist dit ook. 
de curator die zijn taak met nauwgezetheid en inzet vervult. ${ }^{8}$ Bij deze beoordeling moet volgens de Hoge Raad in acht worden genomen dat de curator uiteenlopende, soms tegenstrijdige, belangen moet behartigen en bij het nemen van zijn beslissingen, die vaak geen uitstel kunnen lijden, ook rekening moet houden met belangen van maatschappelijke aard. De norm brengt daarmee tot uitdrukking dat een curator een zekere beleidsvrijheid heeft. ${ }^{9}$ In het Gips-arrest uit 2011 is verduidelijkt dat de Maclou-norm eist dat de curator een persoonlijk verwijt gemaakt kan worden. ${ }^{10}$ Vrij algemeen wordt aangenomen dat daarmee een serieuze mate van schuld wordt vereist. ${ }^{11}$ Sommigen verdedigen zelfs dat, gelijk als bij bestuurdersaansprakelijkheid, de eis van ernstige verwijtbaarheid geldt, ${ }^{12}$ hoewel de Hoge Raad die eis niet expliciet stelt. De norm voor persoonlijke aansprakelijkheid laat in elk geval toe dat (beoordelings)fouten worden gemaakt zonder dat dit meteen tot persoonlijke aansprakelijkheid leidt. ${ }^{13}$ De hiervoor beschreven beleidsvrijheid kan ontbreken, of worden ingeperkt, in gevallen waarin de wet of het (insolventie)recht een specifieke handelswijze aan de curator respectievelijk bewindvoerder voorschrijft. Afwijken van deze handelswijze is niet per definitie persoonlijk verwijtbaar; dat zal steeds op grond van de concrete omstandigheden van het geval beoordeeld moeten worden. Wel geldt logischerwijs dat hoe concreter en dwingender het (faillissements)recht een bepaalde gedragslijn voorschrijft, des te eerder afwijking van die gedragslijn als persoonlijk verwijtbaar aangemerkt kan worden.

Vervult een curator ter uitvoering van zijn taak de rol van bestuurder van een vennootschap, dan geldt overigens voor dat desbetreffende handelen de specifieke norm voor bestuurdersaansprakelijkheid. ${ }^{14}$

Het handelen van de curator of bewindvoerder pro se moet ex tunc beoordeeld worden. ${ }^{15}$ Bepalend is welke informatie destijds voorhanden was. Hierbij moet worden onderkend dat een curator of bewindvoerder veelal met een informatieachter-

8. HR 19 april 1996, ECLI:NL:HR:1996:ZC2047, NJ 1996/727 m.nt. W.M. Kleijn (Maclou).

9. Vgl. Verstijlen 1998, p. 226 e.v.

10. HR 16 december 2011, ECLI:NL:HR:2011:BU4204, NJ 2012/515 m.nt. F.M.J. Verstijlen (Gips).

11. Zie bijv. Hof Den Haag 25 maart 2014, ECLI:NL:GHDHA:2014:891; Hof Amsterdam 29 september 2015, ECLI:NL:GHAMS:2015:4031; R. Vriesendorp, (Schade)claims jegens de curator q.q.; op trustachtige wijze veiliggesteld?, in: M. Faure e.a., De Spier-bundel, Deventer: Wolters Kluwer 2016, p. 127 e.v.

12. J.G. Princen, De aansprakelijkheid van de curator, in: W.W. Korteweg e.a., Capita selecta insolventierecht (Praktijkboek insolventierecht, deel 6), Deventer: Kluwer 2007, p. 116. Vgl. Rb. Den Haag 19 december 2012, zaaknr. 400608/HA ZA 11-2235, niet gepubliceerd, waarin de eis van ernstige persoonlijke verwijtbaarheid wordt gesteld. Zie hierover ook P.S. Bakker \& Y.A. Wehrmeijer, Aansprakelijkheid van de faillissementscurator q.q. en pro se, TvI 2009, afl. 5 .

13. Zie o.m. Borgers 1996; Hof Amsterdam 29 september 2015, ECLI:NL:GHAMS:2015:4031.

14. Hof 's-Hertogenbosch 4 juni 2013, zaaknr. HD 200.099.983/01, niet gepubliceerd.

15. Aldus ook expliciet Hof Leeuwarden 29 september 2004, rolnr. 0400077, niet gepubliceerd. stand kampt en, vooral in de beginfase van de insolventie, in korte tijd vaak een veelheid aan beslissingen moet nemen. Tijd voor uitvoerige analyse en onderzoek ontbreekt soms simpelweg; een curator moet snel knopen (durven) doorhakken. Het feit dat een andere beslissing achteraf gezien, als het stof eenmaal is neergedwarreld, beter was geweest, betekent nog niet dat de destijds gemaakte beslissing verkeerd (althans: persoonlijk verwijtbaar) was. ${ }^{16}$

Aansprakelijkheid q.q. en aansprakelijkheid pro se kunnen naast elkaar bestaan en veelal wordt hoofdelijke veroordeling van de boedel en de curator of bewindvoerder pro se uitgesproken. In de praktijk ziet men ook wel dat primair veroordeling van de boedel wordt gevraagd en subsidiair, voor het geval de boedel geen verhaal biedt, veroordeling van de curator respectievelijk bewindvoerder persoonlijk. Strikt genomen is deze gelaagdheid niet nodig. ${ }^{17}$ Wordt hoofdelijke aansprakelijkheid van boedel en curator of bewindvoerder pro se uitgesproken, dan zal vervolgens ex art. 6:10 jo. art. 6:102 jo. art. 6:101 Burgerlijk Wetboek (BW) in de onderlinge draagplicht tussen hen bepaald moeten worden welk aandeel door welk vermogen gedragen moet worden. Die vraag is vooral relevant in gevallen waarin er actief in de boedel zit; is de boedel leeg, dan zal de schuldeiser de curator of bewindvoerder persoonlijk aanspreken en ontbreekt belang bij regres zijnerzijds op de boedel. In zo'n regresdiscussie kan ongemakkelijk zijn dat de curator of bewindvoerder als het ware met zichzelf moet debatteren over de verdeling van de schade. Soms wordt dit opgelost door hiervoor een nieuwe curator of bewindvoerder aan te stellen. Ook komt het wel voor dat de rechter-commissaris een actievere rol op zich neemt in de draagplichtdiscussie. In veel gevallen zal het aandeel van de curator persoonlijk groter zijn dan dat van de boedel. ${ }^{18} \mathrm{Bij}$ draagplichtdiscussie is echter ook van belang in hoeverre het gewraakte handelen tevens voordelen voor de boedel heeft meegebracht.

Is de insolventie eenmaal beëindigd, dan kan geen vordering meer worden ingesteld tegen de boedel (tegen de curator of bewindvoerder q.q.). ${ }^{19}$ Beëindiging van de insolventie laat onverlet dat de (voormalig) curator of bewindvoerder persoonlijk wordt aangesproken. ${ }^{20}$ Soms kan uit de processtukken niet goed worden opgemakt in welke hoedanigheid de curator of bewindvoerder wordt aangesproken; uiteindelijk is

16. Vgl. Verstijlen 1998 , p. 228; A. Koop, Het kaf van de c(urat)oren, Adv.bl. 2005, afl. 10, p. 488.

17. Vgl. Rb. Middelburg 16 mei 2011, ECLI:NL:RBMID:2011:BR1339.

18. Zie hierover ook I. Spinath, De aansprakelijkheid van de curator - een leidraad, TOP 2010, afl. 5, p. 175 e.v.; Bakker \& Wehrmeijer 2009.

19. HR 29 juni 2012, ECLI:NL:HR:2012:BU5630, NJ 2012/424 (Yukos); Hof Arnhem 9 oktober 2012, ECLI:NL:GHARN:2012:BX9279; Rb. Roermond 5 april 2017, zaak-/rolnr. C/03/219113/HA ZA 16-197, niet gepubliceerd. In Rb. Arnhem 23 februari 2005, ECLI:NL:RBARN: 2005:AT2862 werd geoordeeld dat evenmin een vordering tegen de boedel kon worden vastgesteld indien reeds vaststond dat deze geen enkel verhaal voor de vordering bood.

20. Hof Den Haag 9 december 1997, JOR 1998/138. 
de strekking van de ingestelde vordering dan bepalend. ${ }^{21} \mathrm{Na}$ het ontslag van de curator of bewindvoerder kan zijn opvolger namens de boedel een vordering tegen de voormalig curator of bewindvoerder persoonlijk instellen. Naar mijn mening geldt de hiervoor beschreven norm, ongeacht de vraag of de vordering tegen de curator of bewindvoerder wordt ingesteld door zijn opvolger of door een andere betrokkene. ${ }^{22}$

\subsection{De norm voor bewindvoerders in surseance en schuldsanering}

De hiervoor beschreven norm geldt in beginsel eveneens voor bewindvoerders in surseance van betaling ${ }^{23}$ en bewindvoerders in de schuldsaneringsregeling. ${ }^{24} \mathrm{Wel}$ zal de bijzondere taak van de bewindvoerder bij de invulling van deze norm moeten worden verdisconteerd. Voor een bewindvoerder in surseance van betaling is kenmerkend dat hij, anders dan de faillissementscurator of bewindvoerder in de schuldsaneringsregeling, niet volledig zelf 'aan het stuur' zit. De bewindvoerder in surseance van betaling vervult ex art. 228 Faillissementswet $(\mathrm{Fw})$ meer de rol van bijzitter dan van chauffeur; de bewindvoerder zit naast (het bestuur van) de ondernemer en kan in een noodgeval 'een ruk aan het stuur geven', dat wil zeggen: toestemming onthouden of in het uiterste geval beëindiging van de surseance vragen. De bewindvoerder kan in surseance echter weinig beslissingen eigenmachtig nemen. Daarnaast zal in surseance van betaling veelal nog nadrukkelijker spelen dat er tijdsdruk is en dat de bewindvoerder een informatieachterstand heeft; hij stapt als het ware op een voortdenderende trein, die meestal richting de afgrond dreigt te rijden.

De rol van de bewindvoerder in de schuldsaneringsregeling is grofweg vergelijkbaar met die van de curator in faillissement, in de zin dat zijn taak vooral gericht is op het in het belang van de gezamenlijke schuldeisers vereffenen van het vermogen. Kenmerkend van de schuldsaneringsregeling is dat de bewindvoerder tevens is belast met het toezicht op het door de schuldenaar (een natuurlijk persoon) nakomen van zijn verplichtingen. Daarnaast zal de bewindvoerder in de schuldsaneringsre-

21. Vgl. Rb. Middelburg 11 januari 2012, ECLI:NL:RBMID: 2012:BV1428. Zie voor een meer letterlijke benadering Rb. Zwolle 18 november 1998, zaak-/rolnr. 36946/HA ZA 98-189, niet gepubliceerd.

22. Enigszins anders: GiEA Aruba 16 maart 2016, ECLI:NL:OGEAA: 2016:239, waarin een onderscheid wordt gemaakt tussen (interne) aansprakelijkheid van de (voormalig) curator jegens de boedel en (externe) aansprakelijkheid jegens derden.

23. Hof 's-Hertogenbosch 2 juli 2013, ECLI:NL:GHSHE:2013:2749; Hof 's-Hertogenbosch 22 maart 2005, ECLI:NL:GHSHE: 2005:AT3349; Hof 's-Hertogenbosch 10 februari 2003, ECLI:NL:GHSHE:2003:AF5670; Rb. Haarlem 1 juli 2009, ECLI:NL:RBHAA:2009:BJ6794; Rb. Amsterdam 2 februari 2005, JOR 2005/81; Rb. Alkmaar 19 februari 2003, JOR 2003/126; Rb. Middelburg 22 oktober 1997, JOR 1998/11.

24. Hof Arnhem-Leeuwarden 27 februari 2018, ECLI:NL:GHARL: 2018:1911; Hof Arnhem-Leeuwarden 5 september 2017, ECLI:NL:GHARL:2017:7762; Rb. Noord-Nederland 4 juli 2018, ECLI:NL:RBNNE:2018:2581; Rb. Rotterdam 5 april 2018, ECLI:NL:RBROT:2018:4498; Rb. Overijssel 19 augustus 2015, ECLI:NL:RBOVE:2015:4282; Rb. Utrecht 6 april 2011, ECLI:NL:RBUTR:2011:BR0713; Rb. Haarlem 15 maart 2006, ECLI:NL:RBHAA:2006:AV5290. geling mogelijk extra aandacht moeten hebben voor de persoonlijke belangen van deze schuldenaar, waar de schuldsaneringsregeling erop gericht is dat deze natuurlijk persoon na het doorlopen van de regeling weer verder kan met zijn leven.

Ook ten aanzien van de - (nog) niet bij wet geregelde - stille bewindvoerder in het kader van een prepack geldt een op de specifieke rol van de stille bewindvoerder toegesneden variant van de hiervoor beschreven Maclou-norm. ${ }^{25}$

\subsection{De betekenis van overheidstoezicht en alternatieve regelgeving}

In faillissement, surseance en schuldsaneringsregeling wordt toezicht op de curator of bewindvoerder uitgeoefend door de rechter-commissaris. Het feit dat de rechter-commissaris machtiging of toestemming heeft gegeven voor een bepaalde handeling van de curator of bewindvoerder, vrijwaart hen niet van persoonlijke aansprakelijkheid. ${ }^{26}$ Wel kan het feit dat de rechter-commissaris het handelen tevoren als juist heeft aangemerkt - bijvoorbeeld door daarvoor machtiging te geven - een aanwijzing vormen dat het handelen niet persoonlijk verwijtbaar is. ${ }^{27}$ Spiegelbeeldig kan het ontbreken van de vereiste toestemming van de rechter-commissaris nopen tot de conclusie dat juist wel onzorgvuldig is gehandeld. Uit art. 72 lid $2 \mathrm{Fw}$ volgt bijvoorbeeld dat het door de curator opzeggen van een arbeidsovereenkomst zonder dat de rechter-commissaris machtiging heeft gegeven, de curator in elk geval q.q. aansprakelijk maakt. ${ }^{28}$ Nalaten om de door de wet vereiste toestemming te vragen vormt voorts ten minste een aanwijzing dat tevens persoonlijk verwijtbaar is gehandeld. Handelen in strijd met instructies van de rechter-commissaris zal eveneens al snel persoonlijk verwijtbaar zijn. ${ }^{29}$

Overigens kan onder bijzondere omstandigheden de overheid worden aangesproken voor falend toezicht door de rechtercommissaris. ${ }^{30}$

Bij de invulling van open normen in het aansprakelijkheidsrecht komt betekenis toe aan geschreven regels die zijn opgesteld door een ander dan de wetgever (aangeduid als alternatieve regelgeving of soft law). De specialistenvereniging Insolad hanteert sinds 2004 praktijkregels die een aantal concrete aanbevelingen voor curatoren en bewindvoerders bevatten. De praktijkregels vermelden zelf in de inleiding dat zij geen richtinggevend karakter hebben, terwijl de toelichting op de regels nader verduidelijkt dat afwijking soms aangewezen kan zijn. Dit brengt mee dat het enkele feit dat anders is gehandeld dan de Insolad-praktijkregels voorschreven niet direct tot de con-

25. Vgl. HR 4 oktober 2019, ECLI:NL:HR:2019:1494 en A-G RankBerenschot 24 mei 2019, ECLI:NL:PHR:2019:557.

26. Zie bijv. Hof Den Haag 16 december 2015, JOR 2016/78.

27. Vgl. Verstijlen 1998, p. 369; Rb. 's-Gravenhage 20 april 2011, ECLI:NL:RBSGR:2011:BQ2516.

28. Vgl. HR 26 november 1982, NJ 1983/442.

29. HR 27 november 1998, JOR 1999/72 (Komdeur/Nederlandse Antillen).

30. HR 17 april 1959, NJ 1961/573 (Bloemsma q.q./Staat). 


\section{Maandblad Vermogensrecht}

clusie kan leiden dat (te) onzorgvuldig is gehandeld. ${ }^{31}$ De Recofa-richtlijnen, die zijn opgesteld in overleg met de rechters-commissarissen, hebben eveneens een vrij open karakter. Ook deze richtlijnen laten ruimte voor afwijking, zodat handelen in strijd met die richtlijnen niet meteen tot aansprakelijkheid leidt. ${ }^{32}$ Voorts zal steeds aandacht moeten bestaan voor de relativiteitsvraag uit art. 6:163 BW; de geschreven regels die door Insolad en Recofa zijn opgesteld, strekken niet steeds tot bescherming van het belang van de partij die deze regels inroept. ${ }^{33}$ Curatoren en bewindvoerders worden weliswaar door de rechtbank benoemd, maar zij zijn daarmee nog geen bestuursorganen en de algemene beginselen van behoorlijk bestuur gelden dus niet bij de beoordeling van hun handelen. ${ }^{34}$

\subsection{De positie van de curator/bewindvoerder en aansprakelijkheid voor hulppersonen}

De curator en bewindvoerder in surseance plachten persoonlijk te worden aangesteld. Dat betekent dat alleen zij (persoonlijk) en niet tevens het (advocaten)kantoor waaraan zij verbonden zijn, aansprakelijk kunnen zijn voor het gewrakte handelen. ${ }^{35}$ Kwalitatieve aansprakelijkheid van het kantoor is dus in beginsel niet mogelijk. In schuldsaneringsregelingen komt het regelmatig voor dat een praktijkvennootschap als bewindvoerder wordt benoemd. In dat geval is die vennootschap het aan te spreken ('pro se'-)vermogen en komt aansprakelijkheid van de vennootschap wel aan de orde.

Het hiervoor besproken vereiste van persoonlijke verwijtbaarheid maakt dat een curator of bewindvoerder niet persoonlijk risicoaansprakelijk kan zijn voor fouten van hulppersonen van de boedel, zoals kantoorgenoten, faillissementsmedewerkers of taxateurs. ${ }^{36}$ Risicoaansprakelijkheid voor handelen van anderen is immers een vorm van toerekening anders dan krachtens schuld. Daarnaast kunnen dergelijke personen mijns inziens niet worden beschouwd als een hulppersoon van de curator persoonlijk; deze personen zijn mijns inziens uitsluitend hulppersoon van de boedel. Dat makt dat fouten van deze personen mijns inziens in voorkomend geval wel op grond van art. $6: 170$ of $6: 171 \mathrm{BW}$ aan de boedel kunnen worden toegerekend. Overigens ligt dit alles wat anders als een rechtspersoon als bewindvoerder wordt aangesteld; handelingen van

31. Vgl. HR 4 oktober 2019, ECLI:NL:HR:2019:1494; HR 22 juni 2007, ECLI:NL:HR:2007:BA2511, NJ 2007/520 (ING/Verdonk); Hof Arnhem 11 september 2007, ECLI:NL:GHARN:2007:BB8620, JOR 2007/316; Rb. Amsterdam 24 oktober 2012, ECLI:NL:RBAMS: 2012:BY4491; Rb. Almelo 18 oktober 2006, JOR 2007/56.

32. Vgl. Hof Arnhem-Leeuwarden 24 april 2014, ECLI:NL:GHARL: 2014:3444.

33. Vgl. Hof Den Haag 23 december 2014, ECLI:NL:GHDHA: 2014:4490, JOR 2015/271.

34. Hof Amsterdam 12 april 2011, ECLI:NL:GAMS:2011:BQ3875, JOR 2012/21.

35. HR 10 januari 2003, ECLI:NL:HR:2003:AF0692, NJ 2003/196 m.nt. P. van Schilfgaarde (Van Bentum Recycling/Mrs. Bos c.s. advocaten); Rb. Middelburg 13 april 2011, ECLI:NL:RBMID:2011:BQ2355. Anders: Rb. Rotterdam 14 juli 2010, ECLI:NL:RBROT:2010:BN7875.

36. Rb. Zeeland 3 december 2014, JOR 2015/269; Rb. Utrecht 13 juni 2012, ECLI:NL:RBUTR:2012:BX0507, JOR 2013/347. personeelsleden van deze rechtspersoon - bijvoorbeeld van een schulsaneringskantoor - kunnen op grond van de Kleuterschool Babbel-norm hebben te gelden als handelen van de rechtspersoon, ${ }^{37}$ terwijl art. $6: 170$ of $6: 171 \mathrm{BW}$ hier wel toepassing zou kunnen vinden. Er kan in dat geval sprake zijn van persoonlijke verwijtbaarheid van de als bewindvoerder aangestelde rechtspersoon, terwijl de fout feitelijk is gemaakt door een aan die rechtspersoon verbonden werknemer.

Het feit dat de curator of bewindvoerder persoonlijk wordt aangesteld, maakt blijkens een ouder arrest van de Hoge Raad dat art. 1:88 BW van toepassing kan zijn op door hem aangegane rechtshandelingen. ${ }^{38}$ Voor persoonlijke aansprakelijkheid zal men mijns inziens aan de toepassing van art. 1:88 BW niet snel toekomen, omdat de curator of bewindvoerder de rechtshandelingen volgens mij q.q. en niet pro se zal aangaan.

\section{Gevalstypen}

Hierna wordt aan de hand van de jurisprudentie een aantal categorieën van curatorenaansprakelijkheid onderscheiden en wordt een aantal stelregels uit die rechtspraak opgemaakt. ${ }^{39}$ De aangehaalde rechtspraak betreft in de meeste gevallen een zaak waarin de curator of bewindvoerder (naast q.q. ook) pro se werd aangesproken. Voor de compleetheid van het overzicht worden ook enige uitspraken besproken waarin alleen de boedel was gedaagd. Gezien de brede opzet van dit artikel, worden slechts hoofdregels gegeven, zonder dat per specifiek geval wordt ingegaan op alle mogelijke nuanceringen.

\subsection{Zorgplicht jegens de schuldenaar}

De primaire taak van de curator of bewindvoerder is om het belang van de gezamenlijke schuldeisers te behartigen. Dat laat onverlet dat soms ook tot op zekere hoogte rekening moet worden gehouden met de belangen van de insolvente schuldenaar. Dat speelt bijvoorbeeld bij de keuze om verzekeringen die belangen van de schuldenaar dienen, te beëindigen. Voor levensverzekeringen geldt ex art. 22a Fw een apart toetsingskader en moet de rechter-commissaris betrokken worden in de afkoopbeslissing. ${ }^{40} \mathrm{Bij}$ schadeverzekeringen zal de curator of bewindvoerder moeten afwegen hoe de plicht om premie te betalen zich verhoudt tot het verzekerd belang. Veelal zal ook de boedel zelf belang hebben bij het voortduren van de verzekeringsdekking, zeker waar het gaat om objectverzekeringen. Als de curator er gerechtvaardigd van uit mag gaan dat er deugdelijke verzekeringsdekking is, behoeft hij zelf niet actief

37. HR 6 april 1979, NJ 1980/34 m.nt. C.J.H. Brunner (Kleuterschool Babbel).

38. HR 31 mei 1991, NJ 1991/777 m.nt. E.A.A. Luijten (Fiets-O-Fit/ Knook).

39. Enigszins vergelijkbare overzichten zijn te vinden in: Huijgen, in: GS Onrechtmatige daad, art. 6:162 BW, aant. VI.2.5; Verstijlen, in: GS Faillissementswet, art. 68 Fw, aant. 13; Princen 2007.

40. Zie in het algemeen A-G Verkade 16 juni 2004, ECLI:NL:PHR 2004:AO6920. Zie voor levensverzekering Hof 's-Hertogenbosch 12 februari 2019, ECLI:NL:GHSHE:2019;498, PJ 2019/50 m.nt. W.M.A. Kalkman en E.A.L. van Emden; Rb. Oost-Brabant 21 september 2016, ECLI:NL:RBOBR:2016:5154, JOR 2017/176 m.nt. J.B.A. Jansen. 
voor een verzekering te zorgen. ${ }^{41} \mathrm{Bij}$ verzekeringen die (geheel of vooral) het persoonlijk belang van de schuldenaar dienen, zoals arbeidsongeschiktheidsverzekeringen of aansprakelijkheidsverzekeringen, kan worden gekozen voor het scenario dat de verzekering in stand wordt gelaten en de schuldenaar de premie zelf (uit het vrij te laten bedrag) voldoet. Het is dan de eigen verantwoordelijkheid van de schuldenaar om dergelijke verplichtingen tijdig na te komen. Debat kan ontstaan over de vraag of het de taak van de curator is om uitloopdekking te realiseren onder een beëindigde aansprakelijkheidsverzekering. Relevante gezichtspunten zijn hierbij onder meer of het de curator zelf was die de beëindiging tot stand heeft gebracht, de vraag in hoeverre de boedel in staat is om zelf de premie voor de uitloopdekking te betalen, en de mate waarin aannemelijk is dat die dekking benodigd is. ${ }^{42}$

Vorderingen van de schuldenaar op de curator of bewindvoerder pro se die zijn gegrond op de stelling dat de afwikkeling van de insolventie te lang heeft geduurd, hebben zelden succes. ${ }^{43}$ Ook het feit dat er geen akkoord tot stand is gekomen, zal zelden aan de curator of bewindvoerder toe te rekenen zijn. ${ }^{44}$

De curator moet zorg betrachten bij uitlatingen die hij jegens derden doet over de schuldenaar en over diens rol in de insolventie; het doen van feitelijk onjuiste mededelingen kan pro se onrechtmatig zijn. ${ }^{45}$ Ondertussen zal een curator of bewindvoerder soms een informatieplicht hebben jegens de schuldenaar; het zal daarbij vooral gaan om de noodzaak om feitelijke informatie aan de schuldenaar door te geven. De curator of bewindvoerder heeft in beginsel echter niet de tak om de schuldenaar van (juridisch of financieel) advies te voorzien. ${ }^{46}$ In dat opzicht is de taak van de curator of bewindvoerder wezenlijk anders dan die van een partijadviseur, zoals in het Maclou-arrest ook wordt uitgesproken. ${ }^{47}$

41. Rb. Almelo 6 april 2005, zaaknr. 62426/HA ZA 139, niet gepubliceerd.

42. Dit aspect kwam zijdelings aan de orde in Rb. Rotterdam 20 januari 2016, ECLI:NL:RBROT:2016:444 en Rb. Rotterdam 20 januari 2016, ECLI:NL:RBROT:2016:447.

43. HR 5 september 1997, NJ 1998/31; Hof's-Hertogenbosch 2 juli 2013 , ECLI:NL:GHSHE:2013:2749; Rb. Overijssel 19 augustus 2015, ECLI:NL:RBOVE:2015:4282; Rb. Middelburg 16 mei 2012, ECLI:NL:RBMID:2012:BY0630; Rb. Arnhem 21 juni 2006, ECLI:NL:RBARN:2006:AY5385; Rb. Almelo 10 mei 2000, JOR 2000/133; Rb. Arnhem 20 januari 2000, rolnr. 1998/1314, niet gepubliceerd.

44. Rb. Leeuwarden 28 november 2001, zaaknr. 42578/HA ZA 00-832 (LE), niet gepubliceerd.

45. HR 2 december 1994, NJ 1995/272 (Hack/Jansen); Hof's-Gravenhage 16 augustus 2011, ECLI:NL:GHSGR:2011:BR6094; Hof 's-Hertogenbosch 15 december 1997, JOR 1998/50; Rb. Midden-Nederland 8 mei 2013, ECLI:NL:RBMNE:2013:8029; Rb. Rotterdam 18 mei 1995, KG $1995 / 254$.

46. Hof 's-Hertogenbosch 30 januari 2018, ECLI:NL:GHSHE:2018:346; Hof Amsterdam 12 april 2011, ECLI:NL:GHAMS:2011:BQ3875, NJF $2011 / 255$.

47. HR 19 april 1996, ECLI:NL:HR:1996:ZC2047, NJ 1996/727 (Maclou), zie ook HR 4 oktober 2019, ECLI:NL:HR:2019:1494.
Wanneer het gaat om een schuldenaar die natuurlijk persoon is en er een periodiek aan hem uit te keren vrij te laten bedrag moet worden vastgesteld, heeft de curator of bewindvoerder de zorgplicht om dat tijdig en zorgvuldig te doen. Hierbij is wel van belang dat de curator of bewindvoerder mede afhankelijk is van het door de schuldenaar zelf aanleveren van informatie; levert de schuldenaar geen informatie aan, dan zal hij de curator of bewindvoerder bezwaarlijk kunnen verwijten dat geen vrij te laten bedrag is vastgesteld of uitgekeerd. ${ }^{48}$ De curator of bewindvoerder die inbreuk makt op het vrij te laten bedrag door bijvoorbeeld toeslagen niet aan de schuldenaar door te storten maar aan de boedel toe te voegen, kan daarmee persoonlijk onrechtmatig handelen jegens de schuldenaar. ${ }^{49}$ Dit is echter niet per definitie het geval. ${ }^{50}$

De curator of bewindvoerder zal voorts moeten zorgen voor een adequate (boedel)administratie. ${ }^{51}$ Wanneer het gaat om de keuze om een activum van de schuldenaar, zoals een woonhuis, te gelde te maken, zal de curator in zekere mate rekening moeten houden met de privébelangen van de schuldenaar. Dient executie geen enkel redelijk doel, bijvoorbeeld omdat de hypotheekschuld hoger is dan de executiewaarde, dan kan executie misbruik van recht opleveren. ${ }^{52}$ Als uitgangspunt geldt echter dat een curator of bewindvoerder activa te gelde mag maken, ook als de schuldenaar liever zou zien dat dit achterwege bleef. ${ }^{53}$

Wanneer de insolventie nog niet onherroepelijk is, zal de curator of bewindvoerder een terughoudende opstelling moeten kiezen en onomkeerbare handelingen zo veel mogelijk achterwege moeten laten. ${ }^{54}$ Het onder deze omstandigheden toch verrichten van zulke handelingen is echter niet per definitie persoonlijk verwijtbaar. ${ }^{55}$

\subsection{Zorgplicht in verband met huurovereenkomsten}

De verhouding tussen de curator en de verhuurder wordt in de eerste plaats bepaald door het huurrecht, de huurovereenkomst en art. 39 Fw. In 2018 werd geoordeeld dat de curator die in weerwil van het huurcontract en de expliciete instructies van de verhuurder het verhuurde toch in gebruik gaf aan een derde zonder op enigerlei wijze te garanderen dat de verhuur-

48. Rb. Gelderland 21 augustus 2013, ECLI:NL:RBGEL:2013:6391; Rb. Limburg 31 juli 2013, ECLI:NL:RBLIM:2013:5021.

49. Rb. Haarlem 15 maart 2006, ECLI:NL:RBHAA:2006:AV5290.

50. Rb. Roermond 13 juni 1991, NJ 1992/491.

51. Vgl. Rb. Rotterdam 18 december 2008, ECLI:NL:RBROT: 2008:BH3185.

52. HR 16 januari 2015, ECLI:NL:HR:2015:87, NJ 2015/58 (X/Van der Molen q.q.).

53. Rb. Almelo 28 november 2012, ECLI:NL:RBALM:2012:BY4551

54. HR 11 november 2016, ECLI:NL:HR:2016:257.

55. Hof Arnhem-Leeuwarden 21 mei 2019, ECLI:NL:GHARL: 2019:4450; Rb. Overijssel 10 mei 2017, ECLI:NL:RBOVE:2017:1977. 
der huur ontving, persoonlijk onrechtmatig handelde. ${ }^{56}$ In zijn algemeenheid is het niet persoonlijk verwijtbaar dat de curator of bewindvoerder het gehuurde niet terstond laat ontruimen als de huurovereenkomst nog niet tot een einde is gekomen. ${ }^{57}$ Ook rust er geen rechtsplicht op de curator of bewindvoerder om meteen zelf tot opzegging van de huurovereenkomst over te gaan, waarbij mede van betekenis is dat art. $39 \mathrm{Fw}$ de verhuurder zelf een beëindigingsrecht toekent. ${ }^{58}$ Aansprakelijkheid voor het niet sneller ontruimen kan er wel zijn als de curator of bewindvoerder een op dit punt gedane toezegging zou schenden. ${ }^{59}$ Het feit dat na het intreden van de insolventie de huur onbetaald wordt gelaten, zal als zodanig niet tot persoonlijke aansprakelijkheid van de curator of bewindvoerder leiden, ook niet als de huur met zijn wetenschap door de schuldenaar werd voortgezet. ${ }^{60}$ Een curator mag - anders dan in het geval van een rechtvaardigingsgrond zoals een opschortingsrecht ${ }^{61}$ - niet verhinderen dat een verhuurder na beëindiging van de huurovereenkomst zijn eigendommen terugneemt. ${ }^{62}$ Dat betekent echter niet dat het steeds persoonlijk verwijtbaar is als inventarisatie of wegneming door de verhuurder niet (meteen) gefaciliteerd wordt. ${ }^{63}$ Het collectieve belang van de schuldeisers en het belang van een behoorlijke afwikkeling van de insolventie kunnen in voorkomend geval zwaarder wegen dan het belang van een individuele verhuurder.

Tussen verhuurders en curatoren vindt regelmatig debat plaats over de vraag of een bepaalde zaak van de schuldenaar als gevolg van natrekking of bestanddeelvorming eigendom van de verhuurder is geworden. Daarbij is van belang dat het huurrecht in art. 7:216 BW een wegbreekrecht aan de huurder toekent, dat ook kan worden ingeroepen door de curator. ${ }^{64}$ Dit wegbreekrecht kan echter contractueel zijn uitgesloten en dat moet de curator dan respecteren. Nalaten dit te doen kan tot persoonlijke aansprakelijkheid leiden. ${ }^{65}$

56. HR 9 november 2018, ECLI:NL:2018:2067, NJ 2018/464 m.nt. F.M.J. Verstijlen; Hof Arnhem-Leeuwarden 14 maart 2017, ECLI:NL:GHARL:2017:2116. Zie hierover ook R. Mulder, De persoonlijke aansprakelijkheid van de curator; oppassen geblazen, steeds meer regels! Een overzicht van de stand van zaken, TvI 2019, afl. 1, p. 31-41.

57. Hof's-Hertogenbosch 28 april 2009, ECLI:NL:GHSHE:2009:BI4041.

58. Rb. Groningen 11 juli 2007, zaak-/rolnr. 89124/HA ZA 06-770, niet gepubliceerd.

59. Hof Den Haag 22 februari 2005, NJ 2005/244; Rb. Middelburg 31 juli 2002, JOR 2003/18; Rb. Overijssel 18 december 2013, ECLI:NL:RBOVE:2013:3736. De bewijslast van deze toezegging rust op de verhuurder, zie Rb. Zeeland 3 december 2014, JOR 2015/269; Rb. Arnhem 4 juni 2008, zaak-/rolnr. 164970/HA ZA 08-32, niet gepubliceerd.

60. Rb. Maastricht 27 oktober 2003, ECLI:NL:RBMAA:2003:AN9013.

61. Vgl. Hof Arnhem 20 februari 2007, rolnr. 2005/719 H, niet gepubliceerd.

62. Hof Amsterdam 24 februari 2005, rolnr. 1687/03, niet gepubliceerd; Rb. Zwolle-Lelystad 11 januari 2012, ECLI:NL:RBZLY:2012:BV3060, JOR 2012/366.

63. Rb. Zeeland 3 december 2014, JOR 2015/269.

64. Rb. Noord-Holland 20 december 2017, ECLI:NL:RBNHO: 2017:11385.

65. Zie Rb. Zeeland-West-Brabant 22 mei 2013, ECLI:NL:RBZWB: 2013:CA1252.
Voor schade die al voorafgaand aan de insolventie aan het gehuurde is toegebracht, is de curator logischerwijs niet q.q. (of pro se) aan te spreken. ${ }^{66}$ Voor dergelijke pre-insolventieschade zal veelal wel een vordering in de insolventie ontstaan (faillissementsschuld), maar dit leidt dan niet tot het ontstaan van aansprakelijkheid van de boedel (een boedelschuld). Ontstaat de schade tijdens de looptijd van de insolventie, dan zal de vraag of de boedel, of zelfs de curator persoonlijk, daarvoor aansprakelijk is onder meer afhangen van de vraag of de curator of een hulppersoon van de boedel enige betrokkenheid had bij het ontstaan van de schade. De curator of bewindvoerder moet voorts een zekere zorg jegens de verhuurder in acht nemen bij ingebruikneming van het verhuurde door een derde (waar dat op grond van het huurrecht is toegelaten). Het enkele feit dat de curator of bewindvoerder een derde toegang tot de verhuurde zaak geeft, is nog niet onzorgvuldig; dit wordt anders als er concrete aanwijzingen zijn dat deze derde schade zal veroorzaken. ${ }^{67}$ Het is tot slot niet de taak van de curator om de verhuurder te waarschuwen voor een mogelijk bodembeslag. ${ }^{68}$

\subsection{Zorgplicht in verband met arbeidsovereenkomsten}

De curator kan op grond van art. $40 \mathrm{Fw}$ met machtiging van de rechter-commissaris arbeidsovereenkomsten beëindigen. Laat de curator na om hiervoor de machtiging van de rechtercommissaris te verkrijgen, dan leidt dat ingevolge art. 72 lid 2 Fw in elk geval tot aansprakelijkheid van de boedel; in dat soort situaties is persoonlijke aansprakelijkheid ook denkbaar. ${ }^{69}$ Beëindiging van de arbeidsovereenkomst is in veel faillissementen noodzakelijk omdat de boedel niet in staat is om loon te betalen. Gezien het feit dat de overheid hangende insolventie het loon (binnen bepaalde grenzen) garandeert, heeft de curator ook jegens de overheid een zekere zorgplicht om niet te talmen met opzegging. ${ }^{70}$

Er bestaat onzekerheid over de vraag in hoeverre en wanneer een curator met het oog op het faciliteren van een doorstart een non-concurrentiebeding jegens een (voormalig) werknemer van de schuldenaar kan inroepen. ${ }^{71}$ De curator zal bij zijn beslissing om een beroep op het non-concurrentiebeding te doen ook de belangen van de werknemers moeten meewegen. Het feit dat een doorstarter niet al het personeel van de schuldenaar overneemt, kan niet gemakkelijk aan de curator pro se worden toegerekend. ${ }^{72}$

66. Rb. Den Haag 23 november 2011, ECLI:NL:RBSGR:2011:BV3576, JOR 2012/63.

67. Hof 's-Hertogenbosch 1 mei 2018, zaaknr. 200.169.933/01, niet gepubliceerd.

68. Gem. Hof NA en Aruba 9 december 2008, ECLI:NL:OGHNAA: 2008:BH6237.

69. Vgl. Rb. Almelo 27 april 2005, JOR 2006/26, waar de machtiging van de rechter-commissaris later werd vernietigd.

70. Vgl. Rb. 's-Gravenhage 25 augustus 2010, ECLI:NL:RBSGR: 2010:BN7667 .

71. Hof 's-Hertogenbosch 9 januari 2007, ECLI:NL:GHSHE: 2007:BA9567, JOR 2007/58; Rb. Zutphen 31 augustus 2007, JOR 2008/22.

72. Rb. Almelo 27 juli 2005, JOR 2006/26 
De curator is niet de adviseur van de werknemers van de schuldenaar, maar onder bijzondere omstandigheden moet hij wel extra aandacht voor hun belangen hebben, gezien ook hun relatief zwakkere positie. Dit bracht bijvoorbeeld mee dat de curator eigener beweging een voorrecht moest toepassen dat een werknemer toekwam, maar dat hij zelf niet had ingeroepen. ${ }^{73}$

Is de schuldenaar zelf werknemer, dan zal de arbeidsovereenkomst na zijn faillietverklaring in beginsel blijven doorlopen. De curator zal het loon, voor zover dat het vrij te laten bedrag te boven gaat, aan de boedel toevoegen. De curator heeft in beginsel niet de zorgplicht jegens de werkgever van de schuldenaar om te waken tegen eventuele fraude door de schuldenaar. $^{74}$

\subsection{Zorgplicht in verband met overige overeenkomsten}

Een curator kan niet voorbijgaan aan voor insolventie gesloten overeenkomsten, op het bestaan en de inhoud waarvan het faillissement in beginsel geen verandering brengt. ${ }^{75}$ Weliswaar kan een curator gezien art. $37 \mathrm{Fw}$ niet steeds worden gedwongen tot actieve nakoming van een prefaillissementsovereenkomst (presteren), maar dat geeft hem nog niet de bevoegdheid om aan de inhoud van die overeenkomst voorbij te gaan. ${ }^{76}$ Meer in het bijzonder mag een curator niet zomaar contractuele verplichtingen (waaronder begrepen zogenoemde passieve plichten) om bijvoorbeeld huurgenot te blijven verschaffen, negeren. Het feit dat een curator een prefaillissementsovereenkomst niet gestand doet of naleeft, maakt hem echter nog niet per definitie persoonlijk aansprakelijk. ${ }^{77}$

\subsection{Zorgplicht jegens individuele schuldeisers}

De curator is er primair voor de gezamenlijke schuldeisers, wier belang wordt gediend door het genereren van een maximale boedelopbrengst. Jegens individuele schuldeisers heeft een curator in beginsel geen specifieke zorgplicht, anders dan de hierna te bespreken situatie dat die schuldeiser een eigendoms- of zekerheidsrecht kan inroepen dan wel de schuldeiser zelf een overeenkomst met de boedel sluit. Als er echter een regeling of akkoord in de insolventieregeling wordt getroffen, mag wel van de curator of bewindvoerder worden verwacht dat hij erop toeziet dat alle schuldeisers krijgen waar zij recht

73. Rb. Amsterdam 28 december 2005, ECLI:NL:RBAMS:2005:AU9727.

74. Hof 's-Hertogenbosch 13 september 2011, JOR 2012/60; Rb. Middelburg 16 september 2009, JOR 2010/165.

75. HR 25 mei 1934, NJ 1934, p. 1511 (Helvetia/De Wit)

76. HR 23 maart 2018, ECLI:NL:HR:2018:424, NJ 2018/290 m.nt. F.M.J. Verstijlen (Credit Suisse/Jongepier); HR 11 juli 2014, ECLI:NL:HR: 2014:1681, NJ 2014/407 (Berzona); HR 3 november 2006, ECLI:NL:HR:2006:AX8838, NJ 2007/155 (Nebula). Zie over dit onderwerp nader T.T. van Zanten, Negatieve verplichtingen in faillissement, TvI 2019, afl. 1; G.J. Boekraad, Over fixatie en verificatie van vorderingen, TvI 2019, afl. 1, N.E.D. Faber e.a., Overeenkomsten en insolventie, Deventer: Kluwer 2012.

77. Rb. Gelderland 18 maart 2015, ECLI:NL:RBGEL:2015:2211; Rb. Amsterdam 11 juni 2008, ECLI:NL:RBAMS:2008:BD6619, JOR $2008 / 286$. op hebben. ${ }^{78}$ Voorts moet de curator erop toezien dat ingediende vorderingen correct worden behandeld en dat de schuldeiser die een vordering indient tijdig de juiste informatie ontvangt. ${ }^{79}$ Het enkele feit dat een fout is gemaakt bij het indienings- en afwikkelingsproces betekent echter niet automatisch dat de curator pro se aansprakelijk is. Hierbij speelt ook dat de schuldeiser een verzuim soms nog kan rectificeren, bijvoorbeeld via verzet tegen de uitdelingslijst. ${ }^{80}$

Het feit dat de curator er primair is voor het belang van de gezamenlijke schuldeisers, maakt dat hij geen specifieke zorgplicht heeft jegens bijvoorbeeld de persoon die zich borg heeft gesteld voor schulden van de failliet. ${ }^{81} \mathrm{Bij}$ de wijze waarop de curator of bewindvoerder de insolventie afwikkelt - bijvoorbeeld de vraag hoe hij een doorstart inkleedt -, heeft hij een ruime mate van beleidsvrijheid. ${ }^{82}$

\subsection{Zorgplicht rondom informatieverstrekking}

Zoals vermeld, mag de curator bij het doen van openbare mededelingen, zoals in een openbaar verslag, de belangen van de schuldenaar niet nodeloos schaden. Ook ten aanzien van andere (rechts)personen geldt als uitgangspunt dat de curator in beginsel vrijelijk mededeling mag doen over de staat en gebeurtenissen in de insolventie en dat slechts onder uitzonderlijke omstandigheden een onrechtmatige daad aangenomen wordt. ${ }^{83}$ Echter, het doen van een kenbaar feitelijk onjuiste mededeling kan ook in deze context persoonlijk verwijtbaar zijn. ${ }^{84}$ Wat dit betreft geldt geen wezenlijk andere toets dan in het reguliere aansprakelijkheidsrecht.

Zeker na de intreding van de Algemene verordening gegevensbescherming (AVG) is het maar de vraag of klantenbestanden steeds zomaar door de curator overgedragen kunnen worden. ${ }^{85}$ Eerder werd geoordeeld dat de curator die potentiële kopers inzage geeft in klantenbestanden, in elk geval aandacht moet besteden aan de mogelijke nadelige gevolgen daar-

78. HR 30 maart 2018, ECLI:NL:HR:2018:2067, NJ 2018/464 m.nt. F.M.J. Verstijlen; Hof Arnhem-Leeuwarden 25 oktober 2016, ECLI:NL:GHARL:2016:8586, JOR 2017/50; Hof Arnhem-Leeuwarden 30 januari 2018, ECLI:NL:GHARL:2018:1922; Rb. NoordNederland 3 juni 2015, ECLI:NL:RBNNE:2015:3099.

79. Rb. Rotterdam 5 april 2018, ECLI:NL:RBROT:2018:4498; Rb. Utrecht 6 april 2011, ECLI:NL:RBUTR:2011:BR0713; Rb. Arnhem 28 mei 2003, JOR 2003/242.

80. Rb. Rotterdam 6 augustus 1998, JOR 1999/16.

81. HR 21 maart 2014, ECLI:NL:HR:2014:679, NJ 2014/266 m.nt. T.F.E. Tjong Tjin Tai; Rb. Den Haag 20 maart 2013, ECLI:NL:RBDHA: 2013:BZ9351, JOR 2013/262; Rb. Rotterdam 6 januari 2010, ECLI:NL:RBROT:2010:BL4301, JOR 2010/249.

82. A-G Rank-Berenschot 24 mei 2019, ECLI:NL:PHR:2019:557; Hof Den Haag 28 november 2017, ECLI:NL:GHDHA:2017:3395; Hof Den Haag 28 november 2017, ECLI:NL:GHDHA:2017:3386; Rb. Rotterdam 20 januari 2016, ECLI:NL:RBROT:2016:444; Rb. Rotterdam 20 januari 2016, ECLI:NL:RBROT:2016:448.

83. Rb. Amsterdam 24 oktober 2012, ECLI:NL:RBAMS:2012:BY4491.

84. Hof's-Hertogenbosch 23 mei 1984, NJ 1985/240.

85. Zie hierover M.A.R. Martens, De verkoop van klantenbestanden door de curator. Een confrontatie van het insolventierecht met het privacyrecht, TvI 2018, afl. 2, p. 43-55. 
van, maar dat dit niet per se onzorgvuldig is. ${ }^{86}$ Het is een curator in beginsel toegelaten om derden inzage te geven in de administratie van de schuldenaar. ${ }^{87}$

Onder omstandigheden zal een curator de rechtsplicht hebben om bepaalde informatie aan een specifieke betrokkene te verstrekken. Zo moet de curator de eigenaar of zekerheidsgerechtigde de informatie geven die nodig is om diens goederenrechtelijke aanspraak uit te oefenen. ${ }^{8}$ Hierbij kan bijvoorbeeld worden gedacht aan de noodzaak om pandhouders informatie uit de crediteurenadministratie te geven, zodat verpande vorderingen daadwerkelijk geïnd kunnen worden. Soms zal een curator ook informatie moeten geven die een derde nodig heeft om jegens anderen rechten in te roepen, zoals het geval was toen vanaf de computer van de schuldenaar onrechtmatige uitlatingen over derden werden verstuurd. ${ }^{89}$

\subsection{Zorgplicht bij boedelbeheer, waaronder de wijze van verkoop van activa}

Adequaat boedelbeheer vergt dat de curator tijdig inventariseert welke goederen in de boedel (kunnen) vallen en deze zo veel als mogelijk veiligstelt. ${ }^{90}$ Het enkele feit dat er hangende insolventie goederen verdwijnen of tenietgaan, maakt de curator echter niet automatisch aansprakelijk; de vraag is steeds of de curator voldoende zorg heeft betracht ten aanzien van die zaken en of hem een persoonlijk verwijt kan worden gemaakt van de verdwijning of beschadiging van de zaken. ${ }^{91}$

Bij de wijze waarop de curator de boedel afwikkelt en het actief te gelde maakt, geldt een ruime beleidsvrijheid. ${ }^{92}$ Een curator moet vooral streven naar boedelmaximalisatie, ${ }^{93}$ wat meebrengt dat hij probeert om zo veel mogelijk inkomsten voor de boedel te genereren ${ }^{94}$ en om zo min mogelijk kosten te maken. ${ }^{95}$ Dit impliceert dat telkens een kosten-batenafweging wordt gemaakt. Een curator kan in redelijkheid van verkoop of incasso afzien als de verwachte opbrengsten niet opwegen tegen de begrote kosten. ${ }^{96}$ Deze afweging kan ook meebrengen dat een schikking wordt getroffen in plaats van een procedure wordt gevoerd. ${ }^{97}$ Ook kan dit meebrengen dat wordt gekozen

86. Rb. Rotterdam 22 juli 2015, ECLI:NL:RBROT:2015:6382.

87. Hof Arnhem 11 september 2007, ECLI:NL:GHARN:2007:BB8620, JOR $2007 / 316$.

88. HR 30 oktober 2009, ECLI:NL:HR:2009:BJ0861, NJ 2010/96 m.nt. F.M.J. Verstijlen (Hamm/ABN); Rb. Rotterdam 15 maart 2011, ECLI:NL:RBROT:2011:BP9091.

89. Rb. Breda 3 augustus 2011, ECLI:NL:RBBRE:2011:BR3959.

90. Rb. Alkmaar 19 februari 2003, JOR 2003/126.

91. Rb. Roermond 5 april 2017, zaak-/rolnr. C/03/219113/HA ZA 16-197, niet gepubliceerd; GiEA NA 7 december 1998, JOR 2000/38.

92. Rb. Zutphen 2 mei 2012, zaak-/rolnr. 125105/HA ZA 11-826, niet gepubliceerd.

93. Rb. Amsterdam 2 april 2008, ECLI:NL:RBAMS:2008:BE9581.

94. Rb. Den Haag 8 maart 2017, ECLI:NL:RBDHA:2017:2772.

95. Rb. Gelderland 14 maart 2019, zaaknr. NL18.5827, niet gepubliceerd.

96. Vgl. Hof Den Haag 23 december 2014, ECLI:NL:GHDHA: 2014:4490, JOR 2015/271; Rb. Den Haag 14 november 2012, ECLI:NL:RBSGR:2012:BY3987, JOR 2013/349.

97. Rb. Midden-Nederland 11 december 2013, ECLI:NL:RBMNE: 2013:7252; Rb. Arnhem 20 januari 2000, rolnr. 1998/1314, niet gepubliceerd. voor een snelle zekere verkoop in plaats van het langer zoeken naar een betere opbrengst waarvan onzeker is of die te realiseren is. ${ }^{98} \mathrm{Bij}$ de keuze om activa aan een bepaalde partij te verkopen, kan een rol spelen dat die partij (een deel van) het personeel wil overnemen. ${ }^{99}$ Behoud van werkgelegenheid is immers een maatschappelijk belang waar de curator ook aandacht voor moet hebben. Vanzelfsprekend kan van een curator slechts worden verwacht dat hij activa te gelde maakt als hij het bestaan daarvan kent of redelijkerwijs kan kennen.

Ook bij de wijze waarop de curator activa te gelde maakt, geldt een zekere beleidsvrijheid. ${ }^{100}$ Er moet worden gekozen voor een zorgvuldige verkoopmethode. ${ }^{101} \mathrm{~W}$ at de juiste verkoopmethode is, is contextafhankelijk. Zo is het lang niet altijd nodig om een bodemprijs te hanteren. ${ }^{102}$ De curator zal zich de vraag moeten stellen of de verkoopprijs reëel is; ${ }^{103}$ dat kan soms,${ }^{104}$ maar niet altijd, ${ }^{105}$ voorafgaande taxatie vergen. Taxatie lijkt vooral aangewezen als het gaat om potentieel waardevolle zaken waarvan de waarde lastig zonder waardebepaling door een expert in te schatten valt. Bij overdracht zal de curator zo veel als mogelijk moeten verzekeren dat de koopprijs ook daadwerkelijk door de boedel wordt ontvangen. ${ }^{106}$

Behoren vorderingen tot het vermogen van de schuldenaar, dan zal de curator aandacht moeten hebben voor de tijdige inning daarvan ${ }^{107}$ alsmede voor de tijdige stuiting van de verjaring van deze vorderingen. ${ }^{108}$ Banksaldi moeten zo veel als mogelijk rentedragend worden bewaard. ${ }^{109}$

98. Hof Amsterdam 29 september 2015, ECLI:NL:GHAMS:2015:4031, JOR 2016/19; Rb. Rotterdam 6 januari 2010, ECLI:NL:RBROT: 2010:BL4301, JOR 2010/249.

99. Rb. Arnhem 1 september 2005, ECLI:NL:RBARN:2005:AU3863.

100. Hof Amsterdam 29 september 2015, ECLI:NL:GHAMS:2015:4031, JOR 2016/19; Hof Arnhem-Leeuwarden 23 juni 2015, ECLI:NL:GHARL:2015:4544, JOR 2016/74; Hof Arnhem 8 oktober 2013, ECLI:NL:GHARL:2013:7458; Hof 's-Hertogenbosch 2 juli 2013, ECLI:NL:GHSHE:2013:2749; Hof Arnhem 25 maart 2008, ECLI:NL:GHARN:2008:BC8275.

101. Zie bijv. Rb. Leeuwarden 30 maart 2012, ECLI:NL:RBLEE: 2012:BW5758.

102. HR 16 december 2011, ECLI:NL:HR:2011:BU4204, NJ 2102/515 m.nt. F.M.J. Verstijlen (Gips) met vernietiging van het andersluidende oordeel uit Hof Den Haag 19 november 2013, ECLI:NL:GHDHA: 2013:4275, JOR 2015/79.

103. Hof Amsterdam 27 november 2012, ECLI:NL:GHAMS:2012:3231, Hof Arnhem-Leeuwarden 27 februari 2018, ECLI:NL:GHARL: 2018:1911; Rb. Gelderland 29 maart 2017, ECLI:NL:RBGEL: 2017:2418

104. Rb. Assen 16 februari 2011, ECLI:NL:RBASS:2011:BP8249; Rb. Amsterdam 2 april 2008, ECLI:NL:RBAMS:2008:BE9581; Rb. Assen 10 oktober 2007, zaak-/rolnr. 41828/HA ZA 05-376, niet gepubliceerd.

105. Hof Amsterdam 11 september 2007, ECLI:NL:GHAMS 2007:BB8625, JOR 2007/315; Rb. Utrecht 2 juli 2003, JOR 2003/273.

106. HR 27 november 1998, JOR 1999/72 (Komdeur/Nederlandse Antillen).

107. Rb. Den Haag 20 januari 2010, ECLI:NL:RBSGR:2010:4907, JOR $2010 / 320$.

108. Hof Leeuwarden 13 maart 2002, zaaknr. 0100225, niet gepubliceerd; Rb. Leeuwarden 22 november 2000, nr. H 00/353 (VR), niet gepubliceerd.

109. Hof Den Haag 4 november 1994, JOR 1999/38. 
Zorgvuldig boedelbeheer brengt mee dat de curator slechts uitkeringen vanuit de boedel doet nadat hij heeft vastgesteld dat die betalingen verplicht zijn; zonder rechtsgrond uitbetalen van boedelactief zal al snel persoonlijk verwijtbaar zijn. ${ }^{110}$ De weigering om aan opeisbare verplichtingen te voldoen kan eveneens onzorgvuldig zijn. ${ }^{111}$ Ook overigens mag de curator de boedel niet nodeloos blootstellen aan vermijdbare risico's, zoals het risico dat de boedel twee keer tot nakoming van dezelfde verplichting wordt aangesproken. ${ }^{112}$

Verkoopt een curator activa uit het vermogen van een vof, dan zal hij soms ook de andere vennoten moeten raadplegen. ${ }^{113}$

Bij de verkoop van activa moet de curator bedacht zijn op de mogelijkheid dat zich tussen de goederen van de schuldenaar ook goederen bevinden waarop derden een eigendoms- of zekerheidsrecht kunnen inroepen. Curatoren zullen daarom soms bedingen dat de koper de eigendoms- en zekerheidsrechten van derden respecteert. In beginsel wordt met zo'n beding voldoende rekening gehouden met belangen van mogelijke eigenaren of zekerheidsgerechtigden. ${ }^{114} \mathrm{Zie}$ over de verhouding tussen de curator en de schuldenaar met een goederenrechtelijke aanspraak ook paragraaf 3.8 .

Heeft de curator eenmaal een koopovereenkomst gesloten, dan is het niet zorgvuldig om het feit dat de rechter-commissaris nog daadwerkelijk verlof voor deze onderhandse verkoop moet geven, te gebruiken om die overeenkomst als het ware 'open te breken'. ${ }^{115}$ In contractonderhandelingen zal de curator de precontractuele zorgplicht, zoals de informatieplicht, ${ }^{116}$ moeten naleven; nalaten dat te doen zal in beginsel tot aansprakelijkheid van de boedel leiden en kan in uitzonderlijke gevallen ook tot persoonlijke aansprakelijkheid leiden. Volgens het Gerechtshof Den Haag kan het inlichten van de rechter-commissaris over een later bod onder omstandigheden een schending van deze zorgplicht inhouden, maar was dit niet persoonlijk verwijtbaar. ${ }^{117}$ Onder omstandigheden kan het nalaten om een zekerheidsgerechtigde of medeondernemer te informeren over de beoogde verkoop ook persoonlijk verwijt-

110. Hof Den Haag 9 december 1997, JOR 1998/138; Rb. Utrecht 9 november 2005, zaaknr. 191530/HA ZA 05-517, niet gepubliceerd.

111. Rb. 's-Hertogenbosch 29 juni 1984, NJ 1987/111.

112. Rb. Rotterdam 14 juli 2010, ECLI:NL:RBROT:2010:BN7875.

113. Rb. Arnhem 21 juli 2004, JA 2004/12.

114. HR 30 januari 2015, ECLI:NL:HR:2015:166, JOR 2015/243 (Verwiel q.q./4PET), vervolgd in: Hof Arnhem 26 juli 2016, ECLI:NL:GHARL: 2016:6048, NJF 2016/387. Zie ook HR 19 april 1996, ECLI:NL:HR: 1996:ZC2047, NJ 1996/727 m.nt. W.M. Kleijn (Maclou).

115. HR 7 september 2001, ECLI:NL:HR:2001:ZC3546, JOR 2001/244 (Mayr-Melnhof/Spliet q.q.).

116. HR 8 mei 2009, ECLI:NL:HR:2009:BH1191; HR 14 juli 2000, ECLI:NL:HR:2000:AA6527, JOR 2000/182; Hof Amsterdam 15 september 2005, ECLI:NL:GHAMS:2005:AU7782, JOR 2006/109; Rb. Utrecht 13 juni 2012, ECLI:NL:RBUTR:2012:BX0507.

117. Hof Den Haag 25 maart 2014, ECLI:NL:GHDHA:2014:891, JOR 2014/341; Rb. Dordrecht 13 juni 2012, ECLI:NL:RBDOR: 2012:BW8471, JOR 2013/147. Zie over deze kwestie uitvoeriger F.M.J. Verstijlen, De rol van de rechter-commissaris bij biedingsprocedures, TvI 2014, afl. 3. baar zijn. ${ }^{118} \mathrm{Er}$ is in beginsel geen rechtsplicht om concurrenten te informeren over de beoogde verkoop van activa. ${ }^{119}$

\subsection{Zorgplicht jegens eigenaren en zekerheidsgerechtigden}

De curator of bewindvoerder die in hoedanigheid beschikt over een goed dat niet (onbezwaard) in de boedel valt, handelt daarmee q.q. onrechtmatig. ${ }^{120} \mathrm{Er}$ is dan immers sprake van inbreuk op een recht als bedoeld in art. 6:162 BW, die niet snel verschoonbaar (niet-toerekenbaar) zal zijn. Daarmee is echter nog lang niet gezegd dat de curator of bewindvoerder te dezer zake ook persoonlijk aansprakelijk is. Persoonlijke aansprakelijkheid komt vooral in zicht als de curator of bewindvoerder willens en wetens voorbij is gegaan aan bekende of redelijkerwijs kenbare aanspraken ${ }^{121}$ van derden.

Voorvraag bij dit soort claims is steeds of wel sprake is van een geldig eigendoms- of zekerheidsrecht. ${ }^{122}$ Waar het gaat om de eigendom van, of zekerheidsrechten op, zaken geldt dat de curator ex art. 3:109 jo. art. 3:319 BW als uitgangspunt kan hanteren dat hetgeen hij onder de schuldenaar aantreft, eigendom van de schuldenaar is en dus in de boedel valt. ${ }^{123}$ Dit laat onverlet dat er soms wel een zeker onderzoek gevergd wordt. ${ }^{124}$ Het wettelijk stelsel brengt ondertussen mee dat degene die een goederenrechtelijke aanspraak pretendeert, voor zijn eigen belangen moet opkomen. ${ }^{125}$ De eigenaar respectievelijk zekerheidsgerechtigde moet tijdig en onderbouwd zijn aanspraken inroepen. ${ }^{126} \mathrm{Hij}$ moet dit voldoende duidelijk en indringend doen; een mondelinge of telefonische mededeling zal niet steeds volstaan. ${ }^{127}$ Wordt een voldoende duidelijke aanspraak ingeroepen, dan zal de curator daar

118. Hof Leeuwarden 30 juni 2004, ECLI:NL:GHLEE:2004:AP5415; Hof Arnhem 6 februari 2007, ECLI:NL:GHARN:2007:AZ9951, JOR 2007/106; Rb. Noord-Nederland 4 juli 2018, ECLI:NL:RBNNE: 2018:2581.

119. Hof Arnhem 22 juni 1982, NJ 1983/344.

120. Zie reeds HR 26 mei 1933, NJ 1933/870 m.nt. E.M. Meijers (Bink/ Wiggermans). Zie ook HR 19 december 2003, ECLI:NL:HR: 2003:AN7817, NJ 2004/293 m.nt. Van Schilfgaarde (Mobell/Interplan); Hof 's-Hertogenbosch 27 maart 2018, ECLI:NL:GHSHE: 2018:1291; Hof Den Haag 13 maart 2018, ECLI:NL:GHDHA: 2018:1609.

121. Een curator kan pas rekening houden met aanspraken als hij die kent of redelijkerwijs kan kennen, vgl. Rb. Gelderland 14 maart 2019, zaaknr. NL18.5827, niet gepubliceerd; Rb. Zutphen 2 mei 2012, zaak-/rolnr. 125105/HA ZA 11-826, niet gepubliceerd.

122. Bijv. Hof Arnhem 20 februari 2007, rolnr. 2005/719, niet gepubliceerd; Rb. Overijssel 9 januari 2019, zaak-/rolnr. C/08/199038/HA ZA 17-114, niet gepubliceerd.

123. Vgl. Hof Arnhem 16 oktober 2012, ECLI:NL:GHARN:2012:BY0585, JOR 2013/348; Hof Den Haag 17 november 2009, zaaknr. 105.000.700/01, niet gepubliceerd.

124. Hof Den Haag 13 maart 2018, ECLI:NL:GHDHA:2018:1609; Rb. Amsterdam 14 februari 1996, JOR 1996/28.

125. Vgl. Hof Arnhem 31 maart 2009, ECLI:NL:GHARN:2009:BI2394.

126. Hof Arnhem 16 oktober 2012, ECLI:NL:GHARN:2012:BY0585, JOR 2013/348; Hof Arnhem 11 juli 2006, JOR 2006/302; Rb. Middelburg 16 mei 2011, ECLI:NL:RBMID:2011:BR1339; Rb. Utrecht 16 juni 1999, JOR 1999/186.

127. Rb. Utrecht 16 juli 1999, JOR 1999/186; Rb. Zwolle 18 november 1998, zaak-/rolnr. 36946/HA ZA 98-189, niet gepubliceerd. 
echter niet aan voorbij kunnen gaan. ${ }^{128}$ De curator behoeft niet lang te wachten met het te gelde maken van activa op de grond dat er misschien nog een goederenrechtelijke aanspraak wordt gemeld. ${ }^{129}$ Zie echter wel nog de laatste alinea van deze paragraaf over de specifieke spelregels die gelden in verband met verpande vorderingen. Het is in elk geval niet aan de curator om te bewerkstelligen dat een derde zijn goederenrechtelijke aanspraak kan inroepen. Hij mag het inroepen daarvan echter niet frustreren. ${ }^{130}$ Dat kan soms een informatieplicht impliceren; ${ }^{131}$ maar een curator behoeft niet steeds direct zelf alle schuldeisers te benaderen met de vraag of zij wellicht rechten willen inroepen. ${ }^{132}$ Van de schuldeiser die informatie wil hebben teneinde zijn goederenrechtelijke aanspraken in te roepen, wordt verwacht dat hij voldoende duidelijk maakt welke informatie hij (met welk doel) wil ontvangen. ${ }^{133}$ Het feit dat de curator onjuiste informatie aan een derde verstrekt, is niet steeds persoonlijk verwijtbaar. ${ }^{134}$

Bestaat er slechts een mogelijkheid dat een derde een goederenrechtelijke aanspraak op zaken zal inroepen, dan kan de curator in beginsel tot verkoop overgaan. ${ }^{135}$ De curator doet er verstandig aan om bij die verkoop te bedingen dat de koper de goederenrechtelijke aanspraken van derden zal honoreren (en om dus niet onvoorwaardelijk te garanderen dat het verkochte vrij is van goederenrechtelijke aanspraken van derden). Komt de koper vervolgens zijn verplichting niet na en is revindicatie door de derde ook niet mogelijk, omdat bijvoorbeeld (oneigenlijke) vermenging of zaaksvorming optreedt, dan is de curator daarvoor in beginsel niet persoonlijk aansprakelijk. ${ }^{136}$

Het feit dat zaken van derden in de periode dat zij zich onder de schuldenaar bevinden beschadigd of zoekraken, makt de curator of bewindvoerder als zodanig nog niet persoonlijk aansprakelijk. ${ }^{137}$ Wel moet de curator ook een zekere zorg voor de zaken van derden betrachten (soms aangeduid als de

128. Rb. Amsterdam 14 februari 1996, JOR 1996/28.

129. Hof Amsterdam 29 september 2015, ECLI:NL:GHAMS:2015:4031, JOR 2016/19.

130. Hof Amsterdam 24 februari 2005, rolnr. 1687/03, niet gepubliceerd; Rb. Zwolle-Lelystad 11 januari 2012, ECLI:NL:RBZLY:2012:BV3060, JOR 2012/366; Rb. Amsterdam 2 februari 2005, JOR 2005/81; Rb. Gelderland 25 februari 2015, ECLI:NL:2015:1805, JOR 2015/304. Frustratie is niet snel aan de orde, zo lijkt te volgen uit Rb. Oost-Nederland 30 januari 2013, ECLI:NL:RBONE:2013:BZ0937.

131. Hof Arnhem 31 maart 2009, ECLI:NL:GHARN:2009:BI2394; Rb. Den Haag 17 februari 2016, ECLI:NL:RBDHA:2016:1029.

132. HR 19 april 1996, ECLI:NL:HR:1996:ZC2047, NJ 1996/727 m.nt. W.M. Kleijn (Maclou).

133. Hof Den Haag 26 september 2017, zaaknr. 200.199.521/01, niet gepubliceerd.

134. Rb. Overijssel 5 juni 2013, ECLI:NL:RBOVE:2013:1193.

135. Hof Leeuwarden 3 maart 2009, zaaknr. 109.001.782/01, niet gepubliceerd.

136. HR 19 april 1996, ECLI:NL:HR:1996:ZC2047, NJ 1996/727 m.nt. W.M. Kleijn (Maclou); Hof Arnhem 3 april 2001, ECLI:NL:GHARN: 2001:AB2980.

137. Hof Arnhem 8 oktober 2013, ECLI:NL:GHARL:2013:7458; Hof 'sHertogenbosch 23 september 2003, rolnr. C0200234//BR, niet gepubliceerd; Hof's-Hertogenbosch 21 augustus 1990, NJ 1991/425. zorg van een goed huisvader). ${ }^{138}$ Dit uitgangspunt geldt ook indien door een ongelukkige samenloop van omstandigheden het handelen van de curator, of een van zijn hulppersonen, eraan heeft bijgedragen dat deze beschadiging is ingetreden; dit levert niet per definitie persoonlijke verwijtbaarheid op. ${ }^{139}$

Een curator heeft niet de plicht om een eigenaar of zekerheidsgerechtigde juridisch voor te lichten. ${ }^{140}$ Er kan wel een informatieplicht bestaan ten aanzien van voor de derde relevante feiten. Die informatieplicht is er echter niet als de derde de goederenrechtelijke aanspraak niet (meer) heeft, bijvoorbeeld vanwege vernietiging van diens aanspraak. ${ }^{141}$ Er kan een plicht op de curator of bewindvoerder rusten om de eigenaar of zekerheidsgerechtigde in staat te stellen om een eigen inventarisatie te maken. ${ }^{142}$ Soms vergt goed boedelbelang echter dat de curator de inventarisatie aan een onafhankelijke derde uitbesteedt, en de daaraan verbonden kosten omslaat over de diverse rechthebbenden. ${ }^{143}$

Waar het gaat om (mogelijk) verpande vorderingen heeft de Hoge Raad in een serie arresten een specifieke werkwijze voorgeschreven. ${ }^{144}$ In het kort: de curator mag niet terstond tot inning van vorderingen overgaan, maar moet een wachtperiode (van in beginsel veertien dagen) in acht nemen, zodat pandhouders hun eventuele rechten op deze vorderingen kunnen inroepen. Meldt een pandhouder zich en heeft deze een geldig pandrecht, dan moet de curator van inning afzien. Schendt de curator deze specifieke regels, dan is sprake van onrechtmatige inning, die al snel persoonlijk verwijtbaar zal zijn. ${ }^{145}$ Dit maakt overigens nog niet dat de curator de zorgplicht heeft om anderszins de belangen van de pandhouder te behartigen. Ook hier geldt het uitgangspunt dat degene met de goederenrechtelijke aanspraak voor zijn belangen moet opkomen. De curator behoeft bijvoorbeeld niet ongevraagd ten behoeve van de (bank als) pandhouder incassomaatregelen

138. Rb. Roermond 1 december 2010, zaak-/rolnr. 101366/HA ZA 10-422, niet gepubliceerd.

139. Rb. Roermond 5 april 2017, zaak-/rolnr. C/03/219113/HA ZA 16-197, niet gepubliceerd; Rb. Limburg 23 maart 2016, ECLI:NL:RBLIM:2016:5346.

140. Gem. Hof NA en Aruba 9 december 2008, ECLI:NL:OGHNAA: 2008:BH6237.

141. Hof 's-Gravenhage 28 februari 2008, ECLI:NL:GHSGR: 2008:BC7352.

142. Hof Leeuwarden 3 maart 2009, zaaknr. 109.001.782/01, niet gepubliceerd.

143. Rb. Den Haag 19 juli 1993, NJ 1995/205.

144. HR 5 februari 2016, ECLI:NL:HR:2016:199, NJ 2016/187 (Rabobank/Verdonk); HR 30 oktober 2009, ECLI:NL:HR;2009:BJ0861, NJ 2010/96 (Hamm/ABN), HR 22 juni 2007, ECLI:NL:HR: 2007:BA2511, NJ 2007/520 (ING/Verdonk); HR 17 februari 1995, NJ 1996/471 (Mulder/CLBN).

145. HR 5 februari 2016, ECLI:NL:HR:2016:199, NJ 2016/187 m.nt F.M.J. Verstijlen (Rabobank/Verdonk). Zie eerder al Hof Amsterdam 28 mei 1998, JOR 1999/13; Rb. Almelo 3 augustus 2005, JOR 2006/21. Zie over dit onderwerp uitvoeriger E.A.L. van Emden, Persoonlijke aansprakelijkheid van de curator in verband met verpande vorderingen, MvV 2017, afl. 7-8, p. 243-249. 
te nemen. ${ }^{146}$ Stelt de curator een termijn ex art. $58 \mathrm{Fw}$ aan de pandhouder en laat deze pandhouder deze termijn ongebruikt verstrijken, dan zal de curator in beginsel niet onrechtmatig handelen door daarna het goed te gelde te maken. ${ }^{147}$ Dat zou mogelijk anders kunnen zijn als de curator bij de pandhouder het gerechtvaardigd vertrouwen heeft gewekt dat hij dat niet zal doen. ${ }^{148}$

\subsection{Zorgplicht in verband met voortzetting van de onderneming ${ }^{149}$}

Surseance van betaling is gericht op de voortzetting van de onderneming, zodat uit de aard der zaken volgt dat het bedrijf van de schuldenaar wordt voortgezet. Faillissement en de schuldsaneringsregeling zijn gericht op vereffening. Het kan echter nuttig zijn voor de vereffening dat de onderneming van de schuldenaar tijdelijk wordt voortgezet, bijvoorbeeld omdat zo een project afgemaakt kan worden waarmee inkomsten worden gegenereerd, terwijl het niet afmaken van het project juist zou leiden tot schadeplichtigheid van de schuldenaar. Daarnaast kan tijdelijke voortzetting van het bedrijf de kans op een doorstart en daarmee de kans op een verhoogde verkoopopbrengst en/of behoud van werkgelegenheid vergroten. Is de insolventieregeling nog niet onherroepelijk uitgesproken omdat er een rechtsmiddel is ingesteld, dan zal voortzetting van het bedrijf meestal aangewezen zijn om de waarde te behouden. ${ }^{150}$ Curator en bewindvoerders moeten in deze scenario's goed in de gaten houden dat geen negatief exploitatiesaldo ontstaat; als de kosten de baten structureel dreigen te gaan overschrijden, zal (snelle) beëindiging van de onderneming veelal aangewezen zijn. De curator of bewindvoerder die het bedrijf laat voortzetten terwijl kenbaar is dat de kans op onbetaald blijven van nieuwe schulden te groot is, kan persoonlijk aansprakelijk zijn. ${ }^{151}$ Ook overigens zal de curator respectievelijk bewindvoerder goed controle moeten uitoefenen op wat er gedurende de voortzetting in het bedrijf gebeurt. ${ }^{152}$ Dit maakt echter niet dat het enkele feit dat er hangende de voortzetting van het bedrijf schade wordt veroorzaakt steeds aan de curator of bewindvoerder persoonlijk kan worden toegerekend. Ook het feit dat het uiteindelijk niet mogelijk blijkt te zijn om een tijdens de looptijd van de insolventieregeling door de schuldenaar of boedel aangegane verplichting te laten nakomen, kan niet steeds aan de curator of

146. Rb. Breda 2 mei 2012, zaak-/rolnr. 239065/HA ZA 11-1272, niet gepubliceerd.

147. Hof Den Haag 26 september 2017, zaaknr. 200.199.521/01, niet gepubliceerd.

148. HR 6 februari 2015, ECLI:NL:HR:2015:228, NJ 2015/294; zie eerder Hof 's-Hertogenbosch 9 juli 2013, ECLI:NL:GHSHE:2013:2988, JOR 2014/49.

149. Zie over dit onderwerp in meer algemene zin J.H. Lemstra \& J.H. van der Weide, Kloeke curatoren, in: A.A.M. Deterink e.a. (red.), Doorstart. Insolad jaarboek 2008, Deventer: Kluwer 2008, p. 161 e.v.; M.A.J.G. Janssen, Taken en aansprakelijkheid bewindvoerder, FIP 2010, afl. 5, p. $140-144$.

150. Hof Den Haag 6 juni 2014, JOR 2014/176.

151. Rb. Haarlem 16 februari 2005, JOR 2005/220; Rb. Utrecht 17 maart 1999, JOR 1999/107; Rb. Utrecht 12 juli 2000, JOR 2000/246.

152. HR 18 september 1998, JOR 1998/173; Rb. Oost-Nederland 28 januari 2013, ECLI:NL:RBONE:2013:BY9703. bewindvoerder persoonlijk worden toegerekend. ${ }^{153}$ Dit uitgangspunt geldt vooral in surseance, die nu eenmaal gericht is op voortzetting in een onzeker scenario. Ook een waarschuwingsplicht van de bewindvoerder jegens de schuldeiser voor het mogelijk onbetaald blijven van zijn vordering zal niet snel aan de orde zijn. ${ }^{154}$ Maakt de curator concrete afspraken met een schuldeiser over diens positie, dan zal hij wel zo veel als mogelijk moeten toezien op de nakoming daarvan. ${ }^{155}$ Wordt een toezegging van de curator of bewindvoerder (q.q.) niet gestand gedaan, dan zal dat in elk geval tot boedelaansprakelijkheid leiden. ${ }^{156}$ De toezegging is echter niet pro se gedaan en persoonlijke aansprakelijkheid vergt ook hier dat de curator of bewindvoerder een persoonlijk verwijt gemaakt kan worden. Stelt een eigenaar of zekerheidsgerechtigde dat hangende de voortzetting van de onderneming zaken waarop hij een goederenrechtelijke aanspraak heeft, zijn verbruikt of teniet zijn gegaan, dan worden soms verhoogde eisen gesteld aan de betwisting van die stelling door de curator of bewindvoerder. ${ }^{157}$ Van hem wordt verwacht dat hij heeft laten bijhouden wat er hangende de voortzetting met goederen van derden gebeurt. Voldoet hij niet aan deze verzwaarde stelplicht, dan kan dit leiden tot de vaststelling dat de goederen onder zijn toezicht zijn verbruikt en dat in elk geval de boedel hiervoor aansprakelijk is. Als de curator niet goed kan uitleggen wat er onder zijn toezicht met zaken is gebeurd, dan zal de rechter waarschijnlijk ook snel(ler) aannemen dat de curator op dit punt tevens persoonlijk onzorgvuldig gehandeld heeft.

\subsection{Zorgplicht bijprocederen}

Het enkele feit dat een curator of bewindvoerder een door hem in hoedanigheid gevoerde procedure verliest, betekent vanzelfsprekend nog niet dat hij persoonlijk aansprakelijk is voor de schade van de procedurele wederpartij. De curator of bewindvoerder is niet pro se procespartij. Daarnaast is in zijn algemeenheid het in rechte ongelijk krijgen niet onrechtmatig; onrechtmatig procederen is pas aan de orde in geval van misbruik van recht, hetgeen niet snel het geval is. ${ }^{158}$ Dit uitgangspunt geldt ook voor curatoren en bewindvoerders. De rechtspraak laat zien dat procedurele tegenpartijen hun proceskosten (zoals advocaatkosten en griffierecht) niet snel op de cura-

153. Hof Den Haag 6 juni 2014, JOR 2014/176; Hof's-Hertogenbosch 22 maart 2005, ECLI:NL:GHSHE:2005:AT3349; Hof 's-Hertogenbosch 10 februari 2003, JOR 2003/152; Rb. Maastricht 22 oktober 2003, ECLI:NL:RBMAA:2003:AN9013; Rb. Middelburg 22 oktober 1997, JOR 1998/11.

154. Hof's-Hertogenbosch 4 mei 2004, JOR 2004/255.

155. Rb. Middelburg 31 augustus 2011, ECLI:NL:RBMID:2011:BU9774.

156. Hof Arnhem 5 december 2006, ECLI:NL:GHARN:2006:AZ6556.

157. Hof Leeuwarden 3 maart 2009, zaaknr. 107.001.782/01, niet gepubliceerd.

158. HR 29 april 2016, ECLI:NL:HR:2016:147, NJ 2016/167; HR 6 april 2012, ECLI:NL:HR:2012:BV828, NJ 2012/233. 


\section{Maandblad}

tor persoonlijk kunnen verhalen. ${ }^{159}$ Ook het feit dat de boedel niet in staat blijkt om een uitgesproken proceskostenveroordeling te voldoen, makkt de curator nog niet persoonlijk aansprakelijk. ${ }^{160}$ Er bestaat geen rechtsplicht om in het belang van de procedurele wederpartij een beroep te doen op de zogenoemde garantieregeling. ${ }^{161}$ Dit volgt uit het relativiteitsbeginsel: de garantstellingsregeling beoogt om het aanpakken van specifieke vormen van faillissementsfraude te faciliteren door de curator financiering voor bepaalde typen procedures te verstrekken, niet om verhaal voor proceskosten voor de door de curator aangesproken personen in het leven te roepen. ${ }^{162}$

Legt de curator q.q. beslag en verliest de boedel vervolgens de procedure, dan is de boedel (risico)aansprakelijk voor de schade die het gevolg is van deze beslaglegging. ${ }^{163}$ Hetzelfde geldt als de curator q.q. zijn wederpartij beweegt tot het nakomen van een nog niet onherroepelijke uitspraak, die later wordt vernietigd. ${ }^{164}$ Persoonlijke ansprakelijkheid is dan - behoudens in geval van bijzondere bijkomende omstandigheden ${ }^{165}$ - niet aan de orde. ${ }^{166}$

\subsection{Zorgplicht rondom boedelproblematiek}

De boedel moet worden afgewikkeld met inachtneming van de wettelijke rangorderegels; dat betekent dat betaling van een minder preferente boedelvordering pas kan plaatsvinden nadat alle meer preferente boedelvorderingen geheel zijn

159. Hof Amsterdam 10 april 2011, ECLI:NL:GHAMS:2011:BQ3875, JOR 2012/21; Hof Leeuwarden 19 maart 2008, ECLI:NL:GHLEE: 2008:BC8186; Hof Leeuwarden 13 juli 2005, ECLI:NL:GHLEE: 2005:AT9489, NJF 2005/373; Hof Leeuwarden 17 maart 1999, NJ 2000/27; Rb. Den Haag 27 december 2017, ECLI:NL:RBDHA: 2017:15400; Rb. Limburg 12 oktober 2016, ECLI:NL:RBLIM: 2016:9078, JOR 2017/75; Rb. Zeeland-West-Brabant 31 augustus 2016, zaak-/rolnr. C/02/312566/HA ZA 16-156, niet gepubliceerd; Rb. Noord-Nederland 7 oktober 2015, ECLI:NL:RBNNE:2015:4705; Rb. Amsterdam 24 oktober 2012, ECLI:NL:RBAMS:2012:BY4491; Rb. Almelo 25 april 2012, ECLI:NL:RBALM:2012:BW5203; Rb. Den Haag 20 april 2011, ECLI:NL:GHSGR:2011:BQ2516, NJF 2011/227; Rb. Leeuwarden 14 januari 2004, ECLI:NL:RBLEE:2004:AO2325; Rb. Amsterdam 6 juni 2001, JOR 2001/218; Rb. Breda 19 maart 1996, JOR $1996 / 38$.

160. Hof Leeuwarden 17 maart 1999, NJ 2000/27; Rb. Noord-Nederland 7 oktober 2015, ECLI:NL:RBNNE:2015:4705; Rb. Breda 19 maart 1996, JOR 1996/38.

161. Op grond van de garantstellingsregeling kan het ministerie van Justitie en Veiligheid de curator financiering verstrekken voor (ook) het voeren van procedures uit hoofde van bestuurdersaansprakelijkheid en faillissementspauliana. De garantstellingsregeling omvat dan ook een eventuele proceskostenveroordeling in het nadeel van de boedel.

162. Rb. Den Haag 20 april 2011, ECLI:NL:GBSGR:2011:BQ2516, NJF 2011/227.

163. HR 21 april 2006, ECLI:NL:HR:2006:AV2637; HR 21 februari 1992, NJ 1992/321.

164. HR 11 april 2008, ECLI:NL:HR:2008:BC5602, NJ 2008/225.

165. Rb. Rotterdam 18 mei 2016, ECLI:NL:RBROT:2016:4166; Rb. Leeuwarden 2 maart 2012, ECLI:NL:RBLEE:2012:BV8311.

166. Hof Arnhem-Leeuwarden 1 oktober 2019, ECLI:NL:GHARL: 2019:6950; Rb. Arnhem 12 november 2008, ECLI:NL:RBARN: 2008:BG4558. voldaan. ${ }^{167}$ Dit kan discussies opleveren bij een negatieve boedel, waar het totaal van de boedelschulden groter is dan het boedelactief. In beginsel leidt aansprakelijkheid q.q. tot het ontstaan van een concurrente boedelschuld. Houdt de aansprakelijkheid van de curator q.q. echter verband met de inbreuk op een goed waaraan een voorrecht is verbonden, dan geldt dat voorrecht ook voor de boedelvordering. ${ }^{168}$ Het salaris van de curator is echter een van de meest preferente boedelaanspraken en gaat dus ook voor op veel van de preferente boedelvorderingen. In concreto betekent dit dat een curator die eerst op onrechtmatige wijze boedelactief genereert - bijvoorbeeld door een goed van een derde te gelde te maken en daarmee inbreuk te maken op het recht van die derde -, dat boedelactief veelal kan gebruiken voor betaling van zijn eigen salaris, waardoor de benadeelde derde met lege handen achterblijft. Juist dat heeft geleid tot veel discussie over de vraag of de curator in zo'n geval niet standaard persoonlijk aansprakelijk zou moeten zijn, nu hij als gevolg van zijn eigen onrechtmatige handelen persoonlijk voordeel (salaris) behaalt. Het antwoord op deze vraag is echter dat het op zich niet persoonlijk verwijtbaar is om de boedel overeenkomstig de wettelijke rangorderegels af te wikkelen, ook niet als dit betekent dat de boedelvordering van degene op wiens recht de curator q.q. inbreuk heeft gemaakt, onbetaald blijft. ${ }^{169}$ Er rust geen rechtsplicht op de curator om hetgeen in de boedel zit te separeren of onverwijld terug te betalen aan een boedelschuldeiser.

Er geldt (vooralsnog) één uitzondering, namelijk voor het geval van de na insolventie aan de boedel gedane onverschuldigde betaling die het gevolg is van een kennelijke vergissing. ${ }^{170}$ In dat geval moet de curator wel onverwijld tot terugbetaling overgaan. Voldoet de curator deze superpreferente boedelschuld niet, dan is hij al snel persoonlijk aansprakelijk. ${ }^{171}$ Vanzelfsprekend is toewijzing van deze aanspraak pas aan de orde als wordt voldaan aan de - vrij hoge - eis dat de betaling inderdaad berustte op een evidente vergissing. ${ }^{172}$ Overigens kan in gevallen waarin geen rechtsplicht tot onverwijlde terugbetaling bestaat, soms wel de plicht op de curator rusten om inzage te geven in het verloop van het saldo op de boedelrekening. ${ }^{173}$

167. HR 28 september 1990, NJ 1991/305 m.nt. P. van Schilfgaarde (De Ranitz/Ontvanger).

168. HR 5 februari 2016, ECLI:NL:HR:2016:199, NJ 2016/187 m.nt. F.M.J. Verstijlen (Rabobank/Verdonk).

169. HR 5 februari 2016, ECLI:NL:HR:2016:199, NJ 2016/187 m.nt F.M.J. Verstijlen (Rabobank/Verdonk). In deze zin ook al: Rb. Rotterdam 30 juli 2008, ECLI:NL:RBROT:2008:BF1951, JOR 2008/318. Door deze jurisprudentie is de andersluidende uitspraak van Hof Amsterdam 28 mei 1988, JOR 1999/13 achterhaald.

170. HR 5 september 1997, NJ 1998/437 m.nt. P. van Schilfgaarde (Ontvanger/Hamm); HR 7 juni 2000, ECLI:NL:HR:2002:AE3796, NJ 2002/608 m.nt. J.B.M. Vranken (Komdeur/NN); HR 8 juni 2007, ECLI:NL:HR:2007:AZ4569, NJ 2007/419 m.nt. P. van Schilfgaarde (Van der Werff/BLG).

171. Hof Den Haag 16 december 2015, ECLI:NL:GHDHA:2015:3264, JOR 2016/78; Hof Arnhem 26 november 2002, JOR 2003/46; Rb. Limburg 17 juni 2017, JOR 2017/179.

172. Hof Den Haag 29 mei 2008, JOR 2009/49.

173. Rb. Haarlem 19 december 2000, KG 2001/60. 


\section{Maandblad}

De plicht tot onverwijlde terugbetaling van het door de boedel ontvangen bedrag geldt nadrukkelijk niet in het geval dat een curator op grond van een uitvoerbaar bij voorraad verklaarde uitspraak betaling door de wederpartij bewerkstelligt en de uitspraak later wordt vernietigd. ${ }^{174}$ In dat geval is wel sprake van een onverschuldigde betaling - door de vernietiging is de rechtsgrond immers aan de betaling komen te ontvallen -, maar is niet betaald als gevolg van een kennelijke vergissing. In dat geval heeft de betaler een (in beginsel) concurrente boedelvordering. Het feit dat de boedel veelal niet tot betaling van die boedelvordering in staat is - bijvoorbeeld mede vanwege de kosten die de curator heeft moeten maken voor het hoger beroep -, maakt dat niet anders; dit is een uitvloeisel van het wettelijk systeem. Het feit dat een curator een salarisbeschikking heeft gevraagd en salaris heeft laten uitkeren terwijl de kans bestond dat er nog boedelvorderingen zouden volgen, is niet onrechtmatig. ${ }^{175}$

\section{Overige aspecten van aansprakelijkheid}

Het enkele feit dat de curator toerekenbaar onrechtmatig heeft gehandeld en hem een persoonlijk verwijt kan worden gemaakt, vestigt als zodanig nog geen 'pro se'-aansprakelijkheid. Meer in het bijzonder zal de onrechtmatige daad tevens moeten hebben geleid tot rechtens relevante schade. De stelplicht en bewijslast ten aanzien van het causaal verband en de schade rusten daarbij op grond van de hoofdregel uit art. 149 en 150 Wetboek van Burgerlijke Rechtsvordering $(\mathrm{Rv})$ op de eisende partij. ${ }^{176}$ Het staat de curator of bewindvoerder vrij om een beroep te doen op eigen schuld ex art. 6:101 BW, waarbij de stelplicht en bewijslast dan wel conform de hoofdregels van bewijslast op hem rusten.

Voor schadevergoedingsvorderingen op de curator of bewindvoerder pro se geldt de verjaringsregel uit art. 3:310 BW. ${ }^{177}$ De korte verjaringstermijn uit dat artikel start zodra de schuldeiser bekend wordt met de schade en de aansprakelijke persoon. De verjaringsregel kan complicaties meebrengen indien degene die de curator of bewindvoerder pro se aanspreekt zijn opvolger is. Er kan meer dan vijf jaar zijn gelegen tussen het moment dat de schade werd veroorzaakt door de oorspronkelijke curator en het moment dat de nieuwe curator werd aangesteld. Men kan betogen dat de kennis van de oorspronkelijke curator heeft te gelden als kennis van de boedel en het welbeschouwd de boedel is die de vordering op de curator pro se instelt, zodat vijf jaar nadat de curator die de fout heeft gemaakt bekend is geworden met de schade en zijn rol, de verjaring intreedt. Rechters lijken echter weinig gevoelig

174. HR 7 juni 2000, ECLI:NL:HR:2002:AE3796, NJ 2002/608 m.nt. J.B.M. Vranken (Komdeur/NN); Rb. Zutphen 18 september 2012, ECLI:NL:RBZUT:2012:BX9445, JOR 2013/257.

175. Rb. Rotterdam 16 september 2015, ECLI:NL:RBROT:2015:6571.

176. Zie bijv. Rb. Noord-Nederland 28 augustus 2013, zaak-/rolnr. 62345/ HA ZA 04-89, niet gepubliceerd; Rb. Den Haag 20 januari 2010, ECLI:NL:RBSGR:2010:BL4907, JOR 2010/320.

177. Zie bijv. Rb. Almelo 14 september 2011, ECLI:NL:RBALM: 2011:BT2041. voor dit argument. ${ }^{178}$ Mogelijk kan de verlengingsregeling uit art. 3:321 lid $1 \mathrm{BW}$ hier analoge toepassing vinden.

$\mathrm{Nu}$ de klachtplicht uit art. 6:89 BW niet geldt voor vorderingen uit zuivere onrechtmatige daad, ${ }^{179}$ zal deze bepaling niet vaak een rol kunnen spelen in een beroepsaansprakelijkheidszaak van een curator of bewindvoerder. Een contractuele verhouding tussen de eisende partij en de curator of bewindvoerder persoonlijk zal immers bijna altijd ontbreken (ook als er wel een contractuele verhouding tussen de boedel en die eisende partij bestaat). Een beroep op rechtsverwerking ex art. 6:2(48) lid 2 BW staat wel open, maar zal gezien de aard van het leerstuk slechts in uitzonderlijke gevallen kunnen slagen. ${ }^{180}$

\section{Afrondend}

De rechtspraak leert dat persoonlijke aansprakelijkheid van curatoren en bewindvoerders niet gemakkelijk wordt aangenomen. Dit houdt verband met het toetsingskader dat curatoren en bewindvoerders vrij veel beleidsvrijheid ${ }^{181}$ geeft en tot een zekere terughoudendheid noopt. Persoonlijke aansprakelijkheid wordt vooral aangenomen in gevallen waarin de curator ofwel concrete gedragsvoorschriften schendt, zoals concrete instructies van de rechter-commissaris, ofwel specifieke spelregels van het insolventierecht. Het gaat dan om gevallen waarin minder beleidsvrijheid geldt. Ook komt persoonlijke aansprakelijkheid in zicht in gevallen waarin sprake was van evident onzorgvuldig handelen. In gevallen waarin, terugkijkend, 'slechts' sprake was van ongelukkig handelen, wordt echter veelal niet voldaan aan de eis van persoonlijke verwijtbaarheid.
178. Rb. Rotterdam 14 juli 2010, ECLI:NL:RBROT:2010:BN7875.

179. HR 13 juli 2018, ECLI:NL:HR:2018:1176.

180. Zie bijv. Rb. Rotterdam 16 september 2015, ECLI:NL:RBROT: 2015:6571; Rb. Rotterdam 22 juli 2015, ECLI:NL:RBROT: 2015:6382.

181. Zie bijv. ook Rb. Utrecht 21 maart 2007, ECLI:NL:RBUTR: 2007:BA1590. 